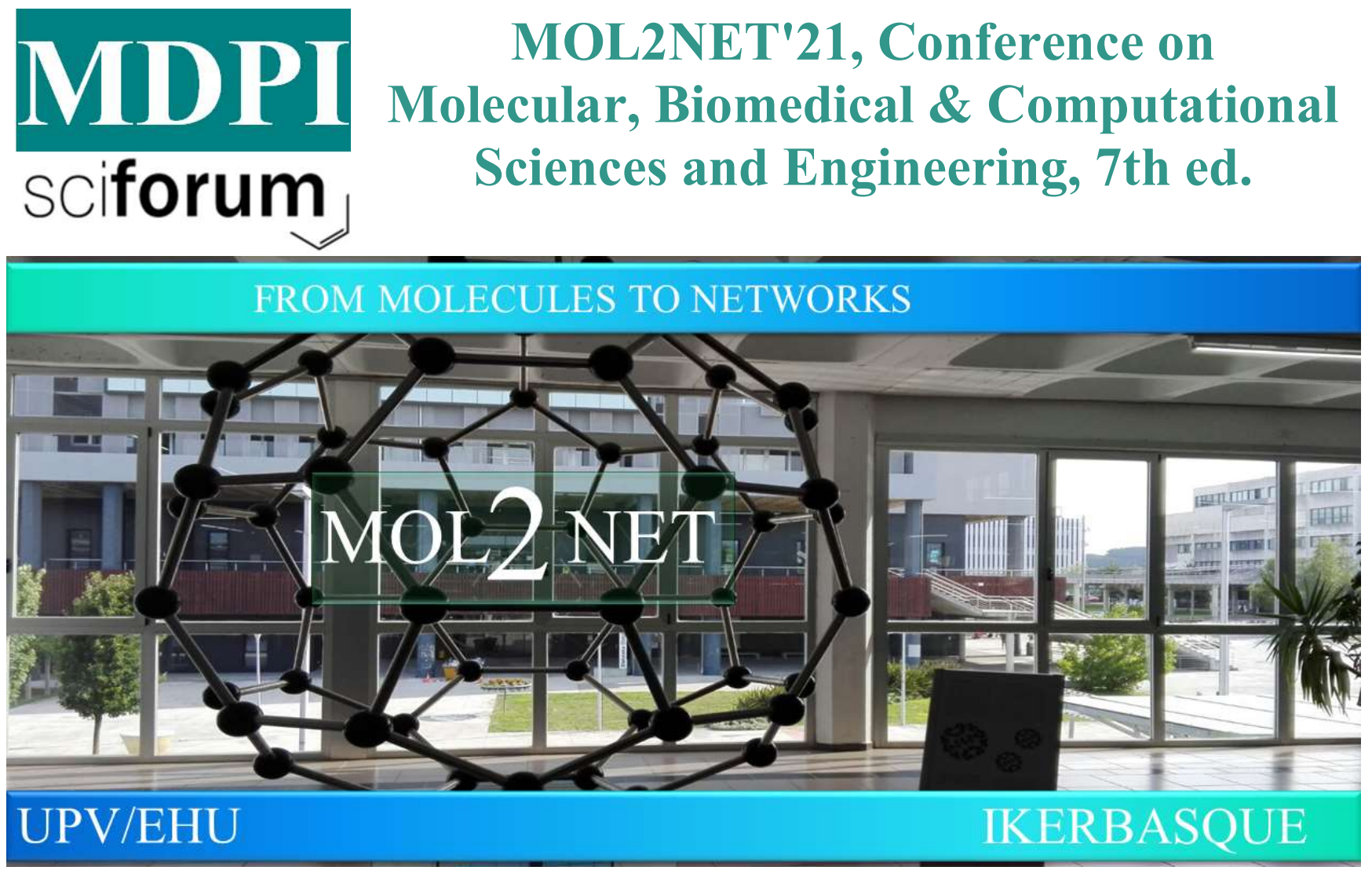

\title{
Effect of an alkaline-thermal pre-treatment and irradiation with accelerated electrons on the enzymatic obtaining of hydrolyzed keratin
}

SamanthaCevallos (samantha.cevallos@epn.edu.ec)

1 Escuela Politécnica Nacional, Facultad de Ingeniería Química y Agroindustria, Quito, Ecuador

\begin{abstract}
On a global scale, millions of tons of feathers are generated annually as a by-product of slaughter in the poultry industry [1]. These, generally tend to be incinerated [2] or disposed in sanitary landfills, which implies a great environmental problem. However, chicken feathers can be a low-cost source of protein since approximately $90 \%$ of its composition corresponds to keratin [3]. Keratin in water-soluble form has different applications in the pharmaceutical, cosmetic, textile, biomedical and food industries [1,4]. The extraction of this protein with sodium sulphide has a high yield; however, it generates hydrogen sulfide gas, which, in high concentrations, can be toxic and difficult to handle [5]. The present research work aimed to establish an enzymatic process to obtain hydrolyzed keratin from chicken feathers; The effect of an alkaline-thermal pretreatment, a pretreatment with ionizing radiation and the combination of both on the amount of soluble keratin obtained was also studied.

The feathers were washed, dried, ground and irradiated, in an electron accelerator, with a dose of $25 k G y$ [6]. The irradiated feather meal was subjected to an alkaline-thermal pretreatment, for which a $0.5 \mathrm{M} \mathrm{NaOH}$ solution was added in an autoclave, for $2 \mathrm{~min}$, at $95^{\circ} \mathrm{C}$. In the supernatant, the amount of protein was quantified by the Biuret method; while, the solid fraction was used for the enzymatic hydrolysis process with trypsin, bromelain or alcalase, under the optimal conditions of temperature and pH for each one. The enzyme that made it possible to obtain the greatest amount of soluble protein was selected. To determine the effects of alkaline-thermal pretreatment and irradiation on the amount of keratin
\end{abstract}


https://mol2net-07.sciforum.net/

recovered, an enzymatic hydrolysis was performed with the selected enzyme, from feather meal without any pretreatment (SIN), only with irradiation (IR), only with the alkaline-thermal pretreatment (AT) and with both processes (IRAT). The results were analyzed in the Statgraphics Centurion 18 program, through an ANOVA and a multiple range test by Fisher's method, with 95\% confidence. Raman analyzes were performed on the irradiated, unirradiated feather meal and the aqueous sample from the IRAT treatment after enzymatic hydrolysis, with a Progeny brand field spectrometer (Rigaku Analytical Devices, Wilmington, USA). The total exposure time for each Raman spectrum was $3 \mathrm{~s}$ and the laser power was $280 \mathrm{~kW}$.

It was determined that alcalase allowed to achieve the best results $(p<0.05)$, followed by trypsin, while the lowest value was obtained with bromelain. On the other hand, with the best treatment (IRAT), 90.31\% of the protein was recovered, in soluble form. In the treatment in which only enzymatic hydrolysis (SIN) was carried out, the least amount of protein was obtained, with a yield of $1.18 \%$.

Exposure of feather meal to ionizing radiation, alkaline conditions and relatively high temperatures and pressures significantly improved the soluble protein yield obtained in a consecutive enzymatic hydrolysis with alkalse. In addition, the treatment of the feather meal with accelerated electrons (IR) increased the performance of the process, compared to the control (feather meal without any pretreatment), but this increase was overshadowed when the feathers were subjected to the alkaline-thermal process. In the Raman spectra, bands corresponding to characteristic groups of the keratin structure were observed, both in feather meal and in soluble protein.

$<E S>$ A escala mundial, millones de toneladas de plumas son generadas anualmente como subproducto del faenamiento en la industria avicola [1]. Estas, generalmente suelen ser incineradas [2] o dispuestas en rellenos sanitarios, lo cual implica una gran problemática ambiental. No obstante, las plumas de pollo pueden ser una fuente de proteina de bajo costo debido a que, aproximadamente, el $90 \%$ de su composición corresponde a queratina [3]. La queratina en forma hidrosoluble tiene distintas aplicaciones en la industria farmacéutica, cosmética, textil, biomédica y alimenticia [1,4]. La extracción de esta proteína con sulfuro de sodio tiene un alto rendimiento; sin embargo, genera gas sulfhídrico, el cual, en altas concentraciones puede ser tóxico y difícil de manipular [5]. El presente trabajo de investigación tuvo como objetivo establecer un proceso enzimático para la obtención de queratina hidrolizada a partir de plumas de pollo; se estudió también el efecto de un pretratamiento alcalino-térmico, un pretratamiento con radiaciones ionizantes y la combinación de ambos sobre la cantidad de queratina soluble obtenida.

Las plumas se lavaron, secaron, molieron e irradiaron, en un acelerador de electrones, con una dosis de $25 \mathrm{kGy}$ [6]. La harina de plumas irradiada se sometió a un pretratamiento alcalino-térmico, para el cual se agregó una solución de $\mathrm{NaOH}$ 0,5 M en autoclave, durante $2 \mathrm{~min}$ a $95^{\circ} \mathrm{C}$. En el sobrenadante se cuantificó la cantidad de proteína por el método de Biuret; mientras que, la fracción sólida se utilizó para el proceso de hidrólisis enzimática con tripsina, bromelina o alcalasa, bajo las condiciones óptimas de temperatura y pH para cada una. Se seleccionó la enzima que permitió obtener la mayor cantidad de proteína soluble. Para determinar los efectos del pretratamiento alcalino-térmico y de la irradiación sobre la cantidad de queratina recuperada, se realizó una hidrólisis enzimática con la enzima seleccionada, a partir harina de plumas sin ningún pretratamiento (SIN), solo con irradiación (IR), solo con el pretratamiento alcalino-térmico (AT) y con ambos procesos (IRAT). Los resultados se analizaron en el programa Statgraphics Centurion 18, a través de un ANOVA y una prueba de rangos múltiples por el método de Fisher, con el $95 \%$ de confianza. Se realizaron análisis Raman en la harina de plumas irradiada, sin irradiar y en la muestra acuosa del tratamiento IRAT después de la hidrólisis enzimática, con un espectrómetro de campo, marca Progeny (Rigaku Analytical Devices, Wilmington, USA). El tiempo total de exposición para cada espectro Raman fue de 3 s y la potencia del láser fue de $280 \mathrm{~kW}$.

Se determinó que la alcalasa permitió conseguir los mejores resultados $(p<0,05)$, seguida de la tripsina, mientras que, con la bromelina se obtuvo el menor valor. Por otro lado, con el mejor tratamiento (IRAT) se recuperó un 90,31\% de la 
https://mol2net-07.sciforum.net/

proteína, en forma soluble. En el tratamiento en el que únicamente se realizó la hidrólisis enzimática (SIN), se obtuvo la menor cantidad de proteína, con un rendimiento de $1,18 \%$.

La exposición de la harina de plumas a radiación ionizante, a condiciones alcalinas y a temperaturas y presiones relativamente altas mejoró significativamente el rendimiento de proteína soluble obtenido en una consecutiva hidrólisis enzimática con alcalasa. Además, el tratamiento de la harina de plumas con electrones acelerados (IR) aumentó el rendimiento del proceso, frente al control (harina de plumas sin ningún pretratamiento), pero este incremento se vio opacado cuando las plumas fueron sometidas al proceso alcalino-térmico. En los espectros Raman se observaron bandas correspondientes a grupos característicos de la estructura de la queratina, tanto en la harina de plumas, como en la proteína soluble.

queratine production, enzymatic hydrolysis; chicken feathers; ionizing radiation 